\title{
Adaption to Hyperoxia
}

\author{
INFLUENCE ON PROTEIN SYNTHESIS BY LUNG AND ON \\ GRANULAR PNEUMOCYTE ULTRASTRUCTURE
}

\author{
Gloria D. Massaro and Donald Massaro \\ From the Pulmonary Division, Veterans Administration Hospital and the \\ Department of Medicine, George Washington University Medical Center, \\ Washington, D. C. 20422
}

A B S T R A C T We studied the influence of prolonged exposure to hyperoxia $\left(\mathrm{O}_{2}>98 \%\right)$ on protein synthesis and on the ultrastructure of the granular pneumocyte. To study protein synthesis, as indicated by $\mathrm{L}-\left[\mathrm{U}-{ }^{14} \mathrm{C}\right]-$ leucine incorporation into protein, lung slices were incubated with radioactive leucine and a surface-active fraction was obtained by ultracentrifugation of lung homogenates. We found that, following an initial depression in protein synthesis after $48 \mathrm{~h}$ of hyperoxia, protein synthesis in rats exposed to oxygen for $96 \mathrm{~h}$ roșe to greater than control levels. This increase in protein synthesis was noted in whole lung protein and in protein present in the surface-active fraction.

Stereologic ultrastructural analysis of granular pneumocytes revealed that the lamellar bodies occupy the same percentage of cytoplasmic volume in oxygen-exposed and control rats after $96 \mathrm{~h}$; a previous study had shown lamellar bodies of oxygen-exposed rats to occupy less volume than those of control rats after $48 \mathrm{~h}$ of exposure at which time protein synthesis was also depressed. After $96 \mathrm{~h}$ of exposure there is a greater amount of rough endoplasmic reticulum in the granular pneumocytes of oxygen-exposed rats.

These studies show that after $96 \mathrm{~h}$ of hyperoxia the lung has recovered its ability to synthesize protein including protein in the surface-active fraction and that these biochemical changes are associated with consistent ultrastructural alterations in the granular pneumocyte.

\section{INTRODUCTION}

In vivo exposure of rats to hyperoxia $\left(\mathrm{O}_{2}>98 \%\right)$ at ambient pressure for $48 \mathrm{~h}$ is associated with decreased

This work was presented in part at the 65th Annual Meeting of the American Society of Clinical Investigation, Inc., Atlantic City, N. J., May 1973.

Received for publication 30 July 1973 and in revised form 12 November 1973. protein synthesis by lung (1). The decrease in the synthesis of protein in a surface-active fraction is greater than the decrease in synthesis of protein in the whole lung homogenate. Within this time there is also a decrease in the volume fraction of lamellar bodies in the pulmonary granular pneumocyte (2); this latter finding is important in relation to the studies on protein biosynthesis because lamellar bodies are considered to be storage sites for pulmonary surfactant (3-7). These biochemical and morphological findings in concert suggest to us that hyperoxia decreases protein synthesis in general but also decreases the synthesis of proteins which are components of macromolecules made for export (secretory proteins), in this instance the apoproteins of pulmonary surfactant.

Since animals may adapt during exposure to hyperoxia (8), the initial part of the present study was undertaken to examine the influence of more prolonged in vivo exposure to hyperoxia on in vitro protein synthesis by lung as measured by the incorporation of radioactive leucine into protein. We found that protein synthesis had returned to control levels or higher after $96 \mathrm{~h}$ of hyperoxia; we then sought to determine if this was associated with ultrastructural changes in the pulmonary granular pneumocyte with particular reference to their lamellar bodies and rough endoplasmic reticulum (RER).

\section{METHODS}

Animals. We used Dublin-Sprague Dawley-derived male rats (Flow Research Animals Inc., Dublin, Va.) weighing between 100-125 g. They were exposed to oxygen $(>98 \%)$ or compressed air and sacrificed as previously described (1).

Incubations of lung slices. Before removing the lungs from the thoracic cavity, the left atrial appendage was excised and the lungs perfused through the pulmonary artery with $10 \mathrm{ml}$ of cold Waymouth medium (Grand Island Bio-

\footnotetext{
${ }^{1}$ Abbreviation used in this paper: RER, rough endoplas-
} mic reticulum. 
logical Co., Grand Island, N. Y.). The lungs were removed and sliced at $1.0-\mathrm{mm}$ thickness using a McIlwain tissue chopper (Brinkmann Instruments, Inc., Westbury, N. Y.). Incubations were performed in Waymouth medium at $40^{\circ} \mathrm{C}$ with L-[U- $\left.{ }^{14} \mathrm{C}\right]$ leucine (New England Nuclear, Boston, Mass.). The gas phase was $95 \% \quad \mathrm{O}_{2}-5 \% \mathrm{CO}_{2}$ and the flasks were shaken at 90 oscillations $/ \mathrm{min}$.

In some studies we performed "pulse-chase" experiments to determine the influence of hyperoxia on the degradation of the newly synthesized protein. To do this we incubated about $75 \mathrm{mg}$ of lung slices with $\mathrm{L}-\left[\mathrm{U}-{ }^{14} \mathrm{C}\right]$ leucine at $40^{\circ} \mathrm{C}$ for $10 \mathrm{~min}$ but used Earle's balanced salt solution $(2.5 \mathrm{ml})$ (Grand Island Biological Co.) as the medium. The flasks (three from each $\mathrm{O}_{2}$ and control rat) were then chilled on ice, the medium removed, and the slices washed quickly with cold Waymouth medium. These slices were then reincubated in Waymouth medium (which contains $0.38 \mu \mathrm{mol}$ of $\mathrm{L}-\left[{ }^{12} \mathrm{C}\right]$ leucine without radioactive leucine) at $40^{\circ} \mathrm{C}$ for 0 or $60 \mathrm{~min}$.

Isolation of surface-active lung fraction. This was done as previously described and basically represents the homogenization of the lung slices followed by two centrifugation steps. The second step results in a pellet, middle zone, and a surface-active pellicle which floats on the middle zone (9). The homogenate, the middle zone, and the pellicle (surface-active fraction) were assayed for acid-insoluble radioactivity and protein $(10,11)$.

Preparation of lung cell-free extracts. In the preparation of the lung cell-free system the lungs were perfused via the pulmonary artery (before removal from the animal) with cold medium which contained $0.35 \mathrm{M}$ ribonuclease-free sucrose (Schwarz/Mann Div., Becton, Dickinson \& Co., Orangeburg, N. Y.), $0.01 \mathrm{M} \mathrm{MgCl}_{2}, 0.025 \mathrm{M} \mathrm{KCl}$, and $0.035 \mathrm{M}$ Tris- $\mathrm{HCl}, \mathrm{pH}$ 7.8. All subsequent procedures were performed between $0-4^{\circ} \mathrm{C}$. The lungs were minced, placed in $10 \mathrm{vol}$ ( $\mathrm{vol} /$ wet weight) of medium, and homogenized by 30 passes of a motor-driven Teflon pestle in a glass homogenizing vessel. The homogenate was centrifuged for $5 \mathrm{~min}$ at $200 \mathrm{~g}$. This produced a pellet, supernatant fluid, and a pellicle which floated on the fluid midzone. The pellicle was removed and the supernatant fluid centrifuged for $20 \mathrm{~min}$ at $15,000 \mathrm{~g}$. This resulted in a pellet which was discarded, the $15,000 \mathrm{~g}$ supernatant material was used for the reaction mixtures.

Cell-free incubation procedures. All incubations were performed in glass test tubes at $40^{\circ} \mathrm{C}$ with $100 \%$ oxygen as the gas phase. The tubes were shaken at 90 oscillations/ min. The complete reaction mixture $(1.44 \mathrm{ml})$ contained $25 \mu \mathrm{mol}$ Tris- $\mathrm{HCl} \mathrm{pH} 7.8,10 \mu \mathrm{mol} \mathrm{MgCl}_{2}, 25 \mu \mathrm{mol} \mathrm{KCl}, 2.5$ $\mu$ mol disodium adenosine 5 -triphosphate, $0.5 \mu \mathrm{mol}$ sodium guanosine 5-triphosphate (GTP), $20 \mu \mathrm{mol}$ trisodium phospho(enol) pyruvate (PEP), $87 \mu \mathrm{g}$ pyruvate kinase (ATP : pyruvate phosphotransferase, E.C. 2.7.1.40), $20 \mu \mathrm{mol}$ reduced glutathione, $2.3 \mathrm{nmol}$ of $\mathrm{L}-\left[\mathrm{U}-{ }^{14} \mathrm{C}\right]$ leucine (sp act 311 $\mu \mathrm{Ci} / \mu \mathrm{mol}$ ), and $0.5 \mathrm{ml}$ of the post $15,000 \mathrm{~g}$ supernatant fluid containing $1.5 \mathrm{mg}$ protein and $0.15 \mathrm{mg}$ RNA. The solutions of GSH were made up fresh immediately before use and their $\mathrm{pH}$ adjusted to 7.4 with Tris base. These chemicals were purchased as follows: ATP and GTP from P-L Biochemicals, Inc., Milwaukee, Wis., GSH, pyruvate kinase, and PEP from Sigma Chemical Co., St. Louis, Mo.

Assay for radioactivity. The tissue proteins and the proteins in the surface-active fraction were precipitated with trichloroacetic acid (TCA), extracted with lipid solvents and hot TCA, and assayed for radioactivity and protein content as previously described $(10,11)$. The hot
TCA-soluble material from the crude extracts was saved for measurement of DNA content relative to the amount of acid-insolube radioactivity.

Chemical determinations. Protein and DNA were measured by using crystallized bovine serum albumin and calf thymus DNA as standards (Mann Research Labs, Inc., New York) $(12,13)$. The content of free leucine in lung tissue was measured using a Beckman amino acid analyzer (Beckman Instruments, Inc., Fullerton, Calif.) as previously described (1). We used unperfused lungs to obtain lung wet weight and percent dry weight. The entire left lung was used in each experiment. The left mainstem bronchus was clamped, the pleural surface gently blotted, and then the bronchi excised at the hilum. The left lung was weighed intact and then sliced in its entirety preparatory to determining the dry weight; it was not blotted after it was sliced. The sliced lung was then placed at $60^{\circ} \mathrm{C}$ and weighed every $24 \mathrm{~h}$. When the weight remained unchanged for $72 \mathrm{~h}$ the lung was considered to be at its dry weight.

Preparation of tissue for electron microscopy and sampling procedures. The tissue was prepared and samples were taken for electron microscopy as described before except that four electron micrographs of granular pneumocytes were taken from each tissue block rather than two as in our previous paper (2). Granular pneumocytes were identified as round or cuboidal cells in the alveolar walls which had signs of attachment as evidenced by a tight junction between it and an adjacent cell. In our initial definition of this cell for the present study, we decided not to require the presence of lamellar inclusion bodies as we had in our previous report (2). We did this because type I alveolar epithelial cells begin to be replaced by type II alveolar epithelial cells (granular pneumocytes) after exposure to hyperoxia for more than $72 \mathrm{~h}(14)$. We were concerned that the new granular pneumocytes might be "immature" and perhaps lack lamellar bodies and that to require their presence might bias the study. As it turned out, all the alveolar epithelial cells fitting these criteria (i.e., round or cuboidal attached cells in the alveolar wall) had lamellar inclusion bodies.

Stereological procedures. Lineal analysis was performed as we previously described including the handling of the micrographs, i.e. blind examination in random order, calculations, and statistical analysis (2).

\section{RESULTS}

Time course of the influence of in vivo oxygen exposure on $\mathrm{L}-\left[U-{ }^{14} \mathrm{C}\right]$ leucine incorporation into protein. The acid-insoluble radioactivity, expressed per milligrams of DNA, is lower in rats exposed to oxygen for $48 \mathrm{~h}$ than in those exposed to compressed air (Fig. 1). This is similar to our previous finding (1). After $72 \mathrm{~h}$ of hyperoxia these differences disappear. By $96 \mathrm{~h}$ of exposure the acid-insoluble radioactivity per milligrams of DNA is higher in the oxygen-exposed rats. When the level of acid-insoluble radioactivity is corrected for the amount of free leucine in the lung (Table I), the difference at $96 \mathrm{~h}$ became even greater. Under these conditions amino acid incorporation into protein is linear with time over the period studied.

In whole cells or tissue slices amino acid incorporation into protein depends on amino acid transport into 
the cell and the synthesis of proteins. To eliminate the need for cell uptake of free leucine we studied protein synthesis in a lung cell-free system. We found that after $7.5 \mathrm{~min}$ of incubation incorporation of $\left[{ }^{11} \mathrm{C}\right]$ leucine into protein, expressed as counts per minute per milligram of RNA, was 4,230 \pm 309 (mean $\pm S E M$ ) for $96 \mathrm{~h}$ compressed air-exposed rats and $6,906 \pm 528$ for oxygenexposed rats $(P=<0.025, n=3)$. Incorporation was linear with time over this interval.

In other experiments where we "pulsed-labeled" lung slices with $\mathrm{L}-\left[\mathrm{U}-{ }^{14} \mathrm{C}\right]$ leucine the lungs from oxygenexposed rats had a greater fall in protein-specific radioactivity $(21.0 \pm 4.3 \%$, mean $\pm \mathrm{SEM}, n=4)$ than rats exposed to compressed air $(14.4 \pm 2.6 \%, n=4)$ but the differences were not statistically significant $(P=0.2)$.

Influence of in vivo oxygen exposure for $96 h$ on $\mathrm{L}-\left[U-{ }^{14} \mathrm{C}\right]$ leucine incorporation into protein of different lung fractions. Based on the time course of the influence of oxygen on protein synthesis we focused attention on the $96 \mathrm{~h}$ period of exposure. The difference between the groups is statistically significant for all fractions expressed per milligrams of DNA in the starting tissue (Fig. 2). The greatest difference between groups is in the protein of the midzone while the smallest difference is in the surface-active fraction. The extent of the difference between the acid-insoluble

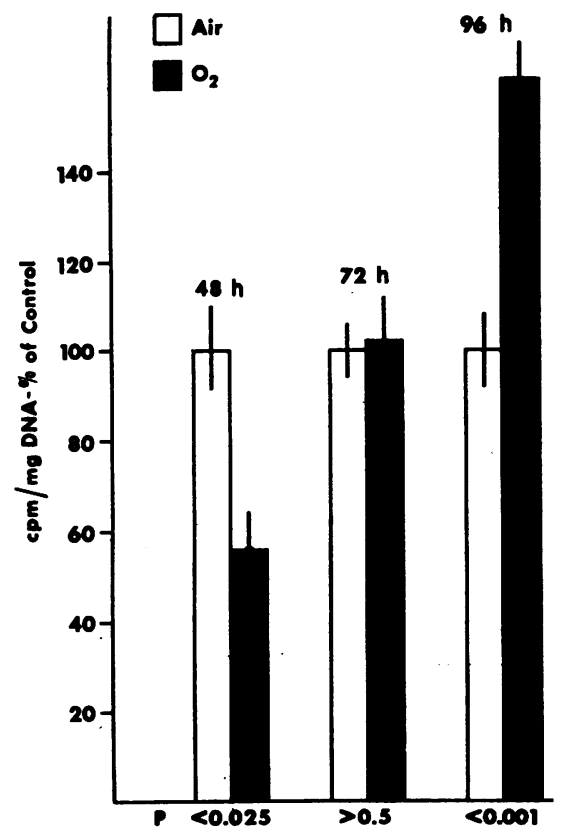

Figure 1 Time course of the influence of in vivo oxygen exposure on $\mathrm{L}-\left[\mathrm{U}-{ }^{14} \mathrm{C}\right]$ leucine incorporation into protein. In each experiment three replicate flasks, from $\mathrm{O}_{2}$ and control rats, containing about $75 \mathrm{mg}$ sliced lung and $10 \mu \mathrm{l}$ of $\mathrm{L}-\left[\mathrm{U}-{ }^{14} \mathrm{C}\right]$ leucine $\left(9.5 \times 10^{-6} \mu \mathrm{mol}: \mathrm{sp}\right.$ act $\left.311 \mu \mathrm{Ci} / \mu \mathrm{mol}\right)$ were incubated in $2.5 \mathrm{ml}$ medium for $60 \mathrm{~min}$. Mean $\pm S E M$ are given. Each value represents five or six animals.

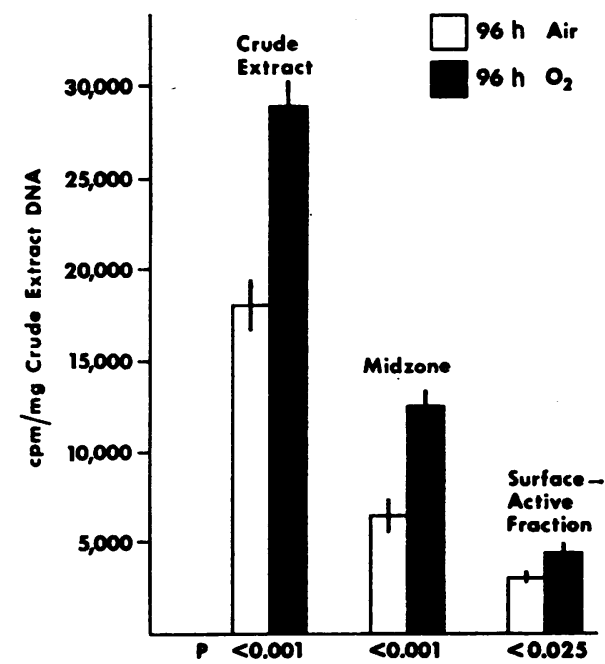

Figure 2 Influence of in vivo oxygen for $96 \mathrm{~h}$ on L$\left[\mathrm{U}-{ }^{14} \mathrm{C}\right]$ leucine incorporation into protein of different lung fractions. In each experiment a single flask, containing about $200 \mathrm{mg}$ of sliced lung tissue in $3.5 \mathrm{ml}$ of medium, was incubated for $60 \mathrm{~min}$ with $25 \mu$ liter of $\mathrm{L}-\left[\mathrm{U}-{ }^{14} \mathrm{C}\right]$ leucine $\left(2.3 \times 10^{-8} \mu \mathrm{mol} ; \mathrm{sp}\right.$ act $\left.311 \mu \mathrm{Ci} / \mu \mathrm{mol}\right)$. Mean $\pm \mathrm{SEM}$ are given. Each value represents seven animals.

radioactivity of the midzone of both groups and the surface-active fraction of both groups is statistically significant $(P=<0.05)$.

Influence of in vivo oxygen on biochemical parameters. Lungs from oxygen-exposed animals are heavier than those from rats exposed to compressed air but the percent dry weight is not different between the groups

TABLE I

Influence of In Vivo Oxygen Exposure on Chemical Composition of the Lung

\begin{tabular}{lccc}
\hline \multicolumn{1}{c}{ Parameter } & Air & $\mathrm{O}_{2}, 96 \mathrm{~h}$ & $P$ \\
\hline Wet weight, $m g^{*}$ & $267 \pm 26$ & $419 \pm 35$ & $<0.001$ \\
& $(4)$ & $(4)$ & \\
Dry weight, $\%^{*}$ & $21.7 \pm 0.1$ & $19.7 \pm 0.5$ & $>0.2$ \\
& $(4)$ & $(4)$ & \\
Protein, $m g^{*}$ & $15.7 \pm 1.0$ & $23.7 \pm 2.8$ & $<0.025$ \\
& $(8)$ & $(7)$ & \\
DNA, $m g^{*}$ & $1.6 \pm 0.1$ & $1.8 \pm 0.1$ & $>0.1$ \\
& $(8)$ & $(7)$ & \\
Protein/DNA & $9.8 \pm 0.4$ & $12.9 \pm 0.8$ & $<0.001$ \\
& $(15)$ & $(14)$ & \\
Leucine, $n m o l$ & $6.1 \pm 0.6$ & $10.1 \pm 1.4$ & $<0.025$ \\
DNA, $m g$ & $(4)$ & $(4)$ & \\
\hline
\end{tabular}

Mean \pm SEM are given.

* Represents value for the entire left lung. The wet weights were determined in unperfused lungs. Values in parentheses indicate the number of animals. 
TABLE II

Influence oj 96 h of Hyperoxia on Granular Pneumocyte Cytoplasmic Components

\begin{tabular}{|c|c|c|c|}
\hline & Air & $\mathrm{O}_{2}, 96 \mathrm{~h}$ & $P$ \\
\hline Number of micrographs & $100(5)$ & $100(5)$ & \\
\hline Total cytoplasmic area, $\mu m^{2}$ & 4,866 & 6,179 & \\
\hline Cytoplasmic area per cell, $\mu m^{2}$ & $49.7 \pm 1.9$ & $61.8 \pm 2.8$ & $<0.01$ \\
\hline \multicolumn{4}{|l|}{ Cytoplasmic volume, $\%$} \\
\hline Mitochondria & $11.3 \pm 0.7$ & $11.8 \pm 0.7$ & $>0.5$ \\
\hline Lamellar bodies & $12.2 \pm 1.2$ & $10.2 \pm 1.1$ & $>0.2$ \\
\hline \multicolumn{4}{|l|}{ Organelle area per organelle } \\
\hline Mitochondria & $0.76 \pm 0.08$ & $0.98 \pm 0.08$ & $<0.1$ \\
\hline Lamellar bodies & $1.10 \pm 0.04$ & $1.28 \pm 0.09$ & $<0.1$ \\
\hline
\end{tabular}

Mean \pm SEM are given. Values in parentheses indicate number of rats. Areas referred to indicate areas of the profile of the cells or intracellular organelles.

(Table I). The lungs of animals exposed to oxygen have a greater protein-DNA ratio and more free leucine than those from animals exposed to compressed air.

Influence of $96 h$ in vivo oxygen on the u!trastructure of the granular pneumocyte. After $96 \mathrm{~h}$ the cytoplasmic area of granular pneumocytes exposed to hyperoxia is greater than that of those exposed to compressed air (Table II). For mitochondria and lamellar bodies there is no difference between the groups in the percent of cytoplasmic volume they occupy or in the organelle area per organelle. After $96 \mathrm{~h}$ of hyperoxia there are no differences in the surface area of lamellar body or mitochondrial envelope between these groups (Table III). The surface density of the RER is however, greater in oxygen compared with compressed air-exposed rats (Table III). The surface density value takes into consideration the greater cytoplasmic area of the granular pneumocyte of the oxygen-exposed group and hence there is both a relative and absolute increase in the amount of RER.

\section{DISCUSSION}

The present study has shown that during continuous exposure to hyperoxia the depression of incorporation of $\left[{ }^{14} \mathrm{C}\right]$ leucine into protein seen at $48 \mathrm{~h}$ is reversed and after $96 \mathrm{~h}$ of exposure incorporation is greater in lung slices from oxygen-exposed rats relative to that in compressed air-exposed rats. In whole cells or tissue slices amino acid incorporation into protein depends on amino acid transport into the cell and on the process of protein synthesis itself. The experiments using the lung cellfree system eliminate the requirement for cell uptake of amino acid. When this is done, the incorporation of $\left[{ }^{14} \mathrm{C}\right]$ leucine into protein, corrected for the free leucine content of the cell-free system, is still higher in the rats exposed to oxygen for $96 \mathrm{~h}$ than in the rats exposed to compressed air. This indicates that at least a portion of the increased incorporation seen in slices from lungs of rats exposed to $\mathrm{O}_{2}$ for $96 \mathrm{~h}$ represents an increase in protein synthesis rather than differences in the specific activity of the tissue free leucine due to differences in leucine transport into the tissue.

The increase in protein synthesis is associated with two important morphological changes which bear upon the interpretation of the biochemical findings. First, there is an increase in the percent cytoplasmic volume occupied by lamellar bodies so that by $96 \mathrm{~h}$ the differences noted at $48 \mathrm{~h}$ (2) between compressed air- and oxygen-exposed animals have been eliminated. This finding is consistent with the finding that there is now no difference in the surface density of the lamellar body envelope between the two groups. Second, after $96 \mathrm{~h}$ of exposure there is a greater amount of RER in the granular pneumocytes of oxygen-exposed animals.

Proteins made for export (secretory proteins) are generally considered to be synthesized on ribosomes of the RER (15). Autoradiographic studies on the lung (5-7) are consistent with the concept, suggested by Macklin (16) and elucidated further by Sorokin (17) and Kuhn (4), that granular pneumocytes synthesize secretory proteins on the RER and store them in the lamellar inclusion bodies. These studies have contributed to the current belief that the lipid and protein moieties of pulmonary surfactant are synthesized by these cells on the RER, and then stored within the lamellar bodies. Viewed in this light the present findings of an increased synthesis of protein in the surface-active fraction, an increased amount of RER and an elimination of the differences in the percent cytoplasmic volume occupied by lamellar bodies between the two groups, indicates there may be an increased synthesis of secretory protein by the lung after $96 \mathrm{~h}$ of hyperoxia as opposed to the decrease noted after $48 \mathrm{~h}$ of hyperoxia.

Kapanci, Weibel, Kaplan, and Robinson (14) have shown that during adaption to prolonged exposure to hyperoxia, the type I alveolar epithelial cells are replaced by type II alveolar epithelial cells (granular

TABLE III

Surface to Volume Ratio of Lamellar Body and Mitochondrial Envelope and Surface Density of RER

\begin{tabular}{lccc}
\hline & Air & $\mathrm{O}_{2}, 96 \mathrm{~h}$ & $P$ \\
\hline Total intersections counted & & & \\
$\quad$ Lamellar body envelope & 3,788 & $3,6.32$ & \\
Mitochondrial envelope & 4,744 & 5,362 & \\
RER & 2,298 & 3,872 & \\
Mitochondrial envelope, $\mu m^{2}$ & $8.50 \pm 0.38$ & $7.41 \pm 0.26$ & $<0.1$ \\
$\begin{array}{c}\text { Mitochondria, } \mu m^{3} \\
\text { Lamellar body envelope, } \mu m^{2}\end{array}$ & $6.35 \pm 0.20$ & $6.04 \pm 0.18$ & $>0.2$ \\
$\quad$ Lamellar body, $\mu m^{3}$ & $0.46 \pm 0.04$ & $0.63 \pm 0.02$ & $<0.01$ \\
$\quad$ RER, $\mu m^{2}$ & & & \\
\hline Cytoplasm, $\mu m^{3}$ & & & \\
\hline
\end{tabular}

Mean $\pm S E M$ are given. Values in parentheses indicate number of animals. 
pneumocytes). The proposed increase in synthesis of secretory protein could be due to the increased number of these cells. However, it is unlikely that this is the sole explanation because of the increased amount of RER within individual granular pneumocytes. It would thus appear that during adaption to hyperoxia, the alveolus is repopulated with granular pneumocytes (14) and that these granular pneumocytes in the oxygen-adapted animals are better able to make secretory protein than those in animals exposed to compressed air.

\section{ACKNOWLEDGMENTS}

We thank Doctors Henry Yeager, Jr., Dorothy Berlin Gail, and Joan Gil for reviewing the manuscript.

This work was supported in part by the American Thoracic Society and U. S. Public Health Service Grants 5S01-RR-5359-11 and HL-16031.

\section{REFERENCES}

1. Gacad, G., and D. Massaro. 1973. Hyperoxia. Influence on lung mechanics and protein synthesis. J. Clin. Invest. 52: 559.

2. Massaro, G. D., and D. Massaro. 1973. Hyperoxia. A stereologic ultrastructural examination of its influence on cytoplasmic components of the pulmonary granular pneumocyte. J. Clin. Invest. 52: 566.

3. Bensch, K., K. Schaefer, and M. E. Avery. 1964. Granular pneumocytes: electron microscopic evidence of exocrinic function. Science (Wash. D. C.). 145: 1318.

4. Kuhn, C., III. 1968. Cytochemistry of pulmonary alveolar lining cells. Am. J. Pathol. 53: 809.

5. Askin, F. B., and C. Kuhn. 1971. The cellular origin of pulmonary surfactant. Lab. Invest. 25: 260.

6. Massaro, G. D., and D. Massaro. 1972. Granular pneumocytes. Electron microscopic radioautographic evi- dence of intracellular protein transport. Am. Rev. Respir. Dis. 105: 927.

7. Chevalier, G., and A. J. Collet. 1972. In vivo incorporation of choline- ${ }^{-} \mathrm{H}$, leucine- ${ }^{3} \mathrm{H}$ and galactose- ${ }^{2} \mathrm{H}$ in alveolar type II pneumocytes in relation to surfactant synthesis. A quantitative radioautographic study in mouse by electron microscopy. Anat. Rec. 174: 289.

8. Clark, J. M., and C. J. Lambertsen. 1971. Pulmonary oxygen toxicity: a review. Pharmacol. Rev. 23: 37.

9. Dickie, K. J, G. D. Massaro, V. Marshall, and D. Massaro. 1973. Amino acid incorporation into protein of a surface-active lung fraction. J. Appl. Physiol. 34: 606.

10. Massaro, D. 1968. Alveolar cells: incorporation of carbohydrate into protein and evidence for intracellular protein transport. J. Clin. Invest. 47: 366.

11. Massaro, D., M. R Simon, and H. Steinkamp. 1971. Metabolic factors affecting protein synthesis by lung in vitro. J. Appl. Physiol. $30: 1$.

12. Lowry, O. H., N. J. Rosenbrough, A. L. Farr, and R. J. Randall. 1951. Protein measurement with Folin phenol reagent. J. Biol. Chem. 193: 265.

13. Schneider, W. C. 1956. Determination of nucleic acids in tissues by pentose analysis. Methods Enzymol. 3: 680 .

14. Kapanci, Y., E. R. Weibel, H. P. Kaplan, and F. R. Robinson. 1969. Pathogenesis and reversibility of the pulmonary lesions of oxygen toxicity in monkeys. II. Ultrastructural and morphometric studies. Lab. Invest. 20: 101.

15. Ganoza, M. C., and C. A. Williams. 1969. In vitro synthesis of different categories of specific protein by membrane-bound and free ribosomes. Proc. Natl. Acad. Sci. U.S. A. 63: 1370.

16. Macklin, C. C. 1954. The pulmonary alveolar mucoid film and the pneumocytes. Lancet. 1: 1099.

17. Sorokin, S. P. 1967. A morphologic and cytochemical study of the great alveolar cell. J. Histochem. Cytochem. $14: 884$. 